\title{
DISTRIBUSI NILAI TAMBAH PADA RANTAI NILAI MEBEL MAHONI JEPARA ${ }^{1}$ (Value Added Distribution Along The Value Chain of Jepara Mabogany Furniture)
}

\author{
Oleh/By: \\ Nunung Parlinah ${ }^{2}$, Herry Purnomo ${ }^{3}$ and Bramasto Nugroho ${ }^{4}$ \\ ${ }^{2}$ Puslitbang Perubahan Iklim dan Kebijakan, Jl. Gunung Batu No.5, Bogor \\ ${ }^{3,4}$ Fakultas Kehutanan-Institut Pertanian Bogor, Kampus IPB Dramaga Bogor \\ e-mail : nparlinah@gmail.com
}

\begin{abstract}
Furniture industry had an important role in foreign exchange revenue in Jepara district. This study proposed to determine the policy scenarios that could encourage the sustainability of furniture industry in Jepara by applying dynamic models. The research was conducted in Jepara District, Sumedang District and KPH Pati on June to November 2008. This study utilized secondary and primary data. The primary data were collected through an interview using a structured questionnaire. The analyses of data involved identification of actors, value chain mapping and distribution of value added. The software, i.e. Stella 8 is applied in modeling and simulation processes. The results showed that there was imbalance of value added distribution per $m^{3}$ raw material along the value chain. There are three scenarios which are possible to be applied, i.e. (1) efficiency in furniture production followed by improving capacity building on the marketing system; (2) the increase of the plantation investment in Perbutani area combined with reducing of forest pressurse and incentive policies on community forest; and (3) fair trade scenario through collective action.
\end{abstract}

Keyword: Value chain, mahogany furniture, Jepara, value added,

\begin{abstract}
ABSTRAK
Industri Furniture memiliki peran penting dalam penerimaan devisa terutama di Kabupaten Jepara. Tujuan dari penelitian ini adalah mengetahui distribusi nilai tambah sepanjang value chain mebel mahoni dan menentukan skenario kebijakan yang dapat mendorong keberlanjutan industri mebel di Jepara dengan menerapkan model dinamis. Penelitian dilakukan di Kabupaten Jepara, Kabupaten Sumedang dan KPH Pati pada bulan Juni Nopember 2008. Data yang digunakan dalam penelitian berupa data sekunder dan data primer. Data primer diperoleh dengan cara wawancara menggunakan kuisioner. Analisis data meliputi identifikasi pelaku, pemetaan rantai nilai dan distribusi nilai tambah. Software Stella 8 digunakan dalam proses pemodelan dan simulasi. Hasil penelitian menunjukkan bahwa terdapat ketidakseimbangan distribusi nilai tambah per $\mathrm{m}^{3}$ bahan baku sepanjang rantai nilai. Terdapat tiga skenario yang dapat diterapkan, yaitu (1) efisiensi dalam produksi mebel diikuti dengan peningkatan kapasitas pengrajin dalam pemasaran; (2) peningkatan penanaman mahoni di areal Perhutani yang dikombinasikan dengan kebijakan pengelolaan yang tepat untuk mengurangi tekanan terhadap hutan dan kebijakan yang bersifat insentif pada hutan rakyat, dan (3) skenario perdagangan yang adil melalui tindakan kolektif.
\end{abstract}

Kata kunci: Rantai nilai, mebel mahoni, Jepara, nilai tambah,

\footnotetext{
${ }^{1}$ Tulisan ini didasarkan pada tesis yang berjudul "Nilai Tambah (Value Chain) Mebel Kayu Mahoni Jepara" dengan dukungan pendanaan dari Australian Centre for International Agricultural Research (ACIAR) Project No. FST/2007/119

"Mahogany and teak furniture: action research to improve value chain efficiency and enhance livelihoods".
}

Distribusi nilai tambah pada rantai ...... (Nunung Parlinah, Herry Purnomo and Bramasto Nugroho) 


\section{PENDAHULUAN}

Penerimaan negara yang berasal dari ekspor mebel terus mengalami peningkatan selama tahun 2000 - 2005 yaitu sebesar 17\% (selama periode tersebut) dengan jumlah ekspor mencapai US\$1,78 milyar pada tahun 2005 (USAID-SENADA, 2007), dimana 75 persennya merupakan mebel kayu (ASMINDO Komda Jepara, 2008). Dalam perdagangan global, mebel Indonesia selama tahun 2003 - 2005 hanya menguasai 2,5\% dari pangsa pasar dunia (USAID - SENADA, 2007), sementara perkembangan pangsa pasar China meningkat dari 3\% pada tahun 1995 menjadi 17\% di tahun 2005 (ITTO 2006). Pesatnya perkembangan mebel China tersebut akan berpengaruh terhadap penurunan pangsa pasar mebel Indonesia.

Selain mendatangkan devisa, keuntungan lain yang diperoleh dari bisnis mebel adalah penciptaan lapangan kerja, hal ini dapat dilihat dari banyaknya unit industri dan tenaga kerja yang terlibat. Sebagai contoh, pada tahun 2005 jumlah industri mebel di Jepara, sebagai sentra industri mebel, mencapai 15.271 unit dengan jumlah tenaga kerja 176.470 orang (Roda et. al, 2007). Sektor ini memberikan kontribusi yang tinggi pada Produk Domestik Regional Bruto (PDRB) Kabupaten Jepara. Pada tahun 2006, kontribusi dari sektor industri pengolahan adalah sebesar 27\%, dimana 84,8\% dari sektor tersebut berasal dari industri kayu dan hasil hutan lainnya (BAPPEDA dan BPS Kabupaten Jepara, 2007).

Banyaknya industri mebel di Jepara telah mengakibatkan terjadinya persaingan antar pelaku dalam bisnis mebel termasuk dalam memperoleh bahan baku. Menurut Roda et al. (2007) konsumsi kayu di Jepara mencapai 1,5 - 2,2 juta $\mathrm{m}^{3}$ per tahun dengan jenis-jenis kayu yang digunakan antara lain meliputi kayu jati, mahoni, akasia dan kayu dari hutan alam. Selain adanya tantangan berupa turunnya ketersediaan kayu yang berkualitas serta mekanisme distribusi dan pemasaran kayu (Ewasechko, 2005), distribusi pendapatan yang tidak seimbang dan tekanan pada kelestarian tanaman juga merupakan tantangan tersendiri (Purnomo, 2006). Adanya hubungan kerjasama antara principal (pemberi kepercayaan) dan agent (penerima kepercayaan) yang terjadi antar aktor di dalam rantai juga menentukan besarnya distribusi keuntungan yang diperoleh masing-masing pelaku.

Menurut ITTO (2006), perkembangan permintaan mebel diperkirakan meningkat sebesar lebih dari 3\% di beberapa negara. Di lain pihak, semua jenis mahoni yaitu Switenia macrophylla, S. mahagoni dan S. bumilis masuk dalam Appendix CITES II yang berimplikasi pada perlunya ijin ekspor dari negara asal kayu dan perlunya ijin impor di beberapa negara tujuan (CITES 2007). Kondisi ini menjadi peluang bagi Indonesia untuk meningkatkan produksi mebel mahoni dalam rangka memenuhi pasar, karena pemanenan kayu mahoni di tempat tumbuh aslinya yaitu Benua Amerika dibatasi. Peluang Indonesia tersebut didukung dengan besarnya potensi produksi mahoni yang ada.

Melihat banyaknya pelaku yang terlibat di sepanjang value chain mebel, banyaknya tenaga kerja yang kehidupannya tergantung dari keberlangsungan pasokan bahan baku serta peluang pasar yang ada, maka tujuan dari tulisan ini adalah mengetahui distribusi nilai tambah sepanjang value chain mebel mahoni serta mencari skenario kebijakan yang dapat mendorong kelangsungan industri mebel melalui pendekatan sistim dinamik. 


\section{METODE PENELITIAN}

Rantai nilai mebel dapat digolongkan sebagai buyer driven yaitu rantai nilai dimana pengecer atau pedagang besar mendominasi aturan-aturan dalam sistem produksi. Sistem produksi yang dikendalikan antara lain model dan spesifikasi produk yang akan dibuat. Karakteristik lain dari rantai nilai mebel adalah banyaknya pelaku yang terlibat yang saling berhubungan sehingga membentuk jaringan yang kompleks. Setiap pelaku di sepanjang rantai nilai melakukan berbagai kegiatan yang dapat memberikan nilai tambah pada setiap prosesnya. Besarnya distribusi nilai tambah yang diterima masing-masing pelaku tersebut dapat berpengaruh terhadap kelestarian usaha mebel.

Dengan melihat adanya keterkaitan berbagai faktor yang mempengaruhi kelangsungan industri mebel, maka dikembangkan model dinamik dari luas tanaman mahoni dan produksi kayu mahoni sebagai sumber bahan baku, perdagangan kayu dan distribusi nilai tambah. Secara ringkas kerangka pemikiran dari penelitian rantai nilai mebel mahoni seperti terlihat pada Gambar 1.

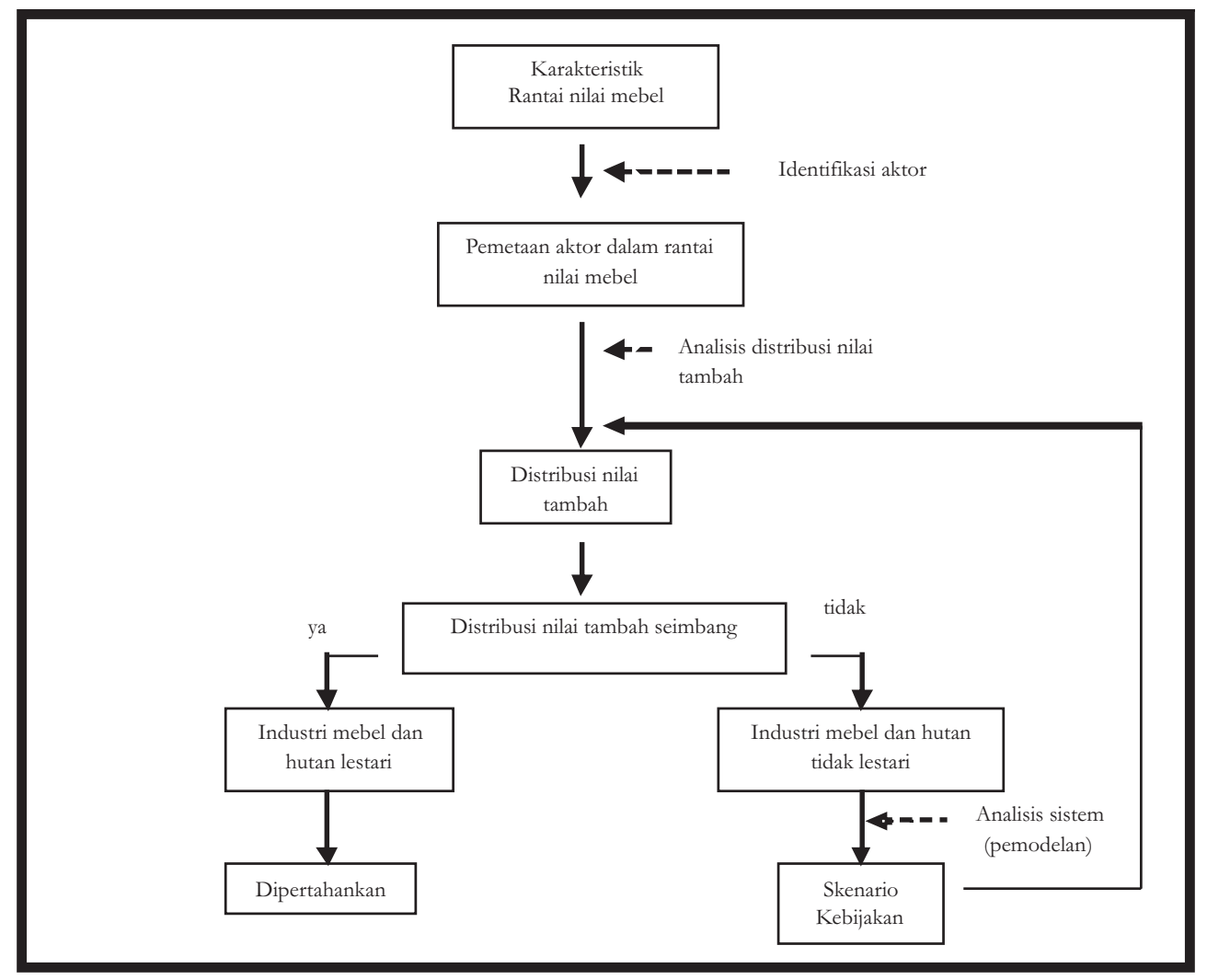

Gambar 1. Kerangka pemikiran penelitian.

Figure 1. Research framework.

Distribusi nilai tambah pada rantai ...... (Nunung Parlinah, Herry Purnomo and Bramasto Nugroho) 


\section{A. Lokasi dan Waktu Penelitian}

Lokasi penelitian dilaksanakan di Kabupaten Jepara - Propinsi Jawa Tengah, Kabupaten Sumedang - Propinsi Jawa Barat, dan KPH Pati - Perum Perhutani Unit I Jawa Tengah. Waktu penelitian dilaksanakan pada bulan Juni sampai bulan Nopember 2008.

\section{B. Pengumpulan Data}

Data yang dikumpulkan dalam penelitian ini meliputi data primer dan data sekunder. Data primer diperoleh melalui wawancara dengan responden dengan menggunakan kuisioner. Menurut Kaplinsky dan Morris (2000); Kaplinsky et al. (2003), rantai nilai untuk industri mebel termasuk dalam kategori buyer driven. Dengan asumsi ini, maka penelitian dilakukan dengan cara backward yaitu melihat keterkaitannya ke belakang. Pengambilan sampel dilakukan dengan metode snowball (tidak termasuk KPH Pati dan petani), dimana aktor-aktor yang menjadi responden dalam penelitian ini adalah: (a) eksportir (+finishing), (b) pengecer/toko domestik (+finishing), (c) perusahaan jasa finishing, (d) pengrajin mebel yang terbagi menjadi 2 kelompok yaitu pengrajin yang memproduksi mebel untuk pasar domestik dan pengrajin yang memproduksi mebel untuk pasar ekspor, (e) perusahaan jasa penggergajian, (f) pedagang kayu di Jepara dan di Sumedang, (g) petani di Kabupaten Sumedang, dan (h) Perhutani KPH Pati.

Sedangkan data sekunder yang digunakan dalam penelitian antara lain meliputi: (a) data volume dan nilai penjualan mebel di Kabupaten Jepara; (b) data tujuan penjualan mebel dari Kabupaten Jepara; (c) data potensi tegakan mahoni Perhutani KPH Pati; (d) data potensi tegakan mahoni yang berasal dari rakyat di Kabupaten Sumedang. Data sekunder tersebut berasal dari instansi terkait antara lain Dinas Perindustrian Perdagangan, Koperasi dan Penanaman Modal Kabupaten Jepara, Dinas Kehutanan dan Perkebunan Kabupaten Jepara, Biro Pusat Statistik (BPS) Kabupaten Jepara, Perum Perhutani Unit I Jawa Tengah, Perhutani KPH Pati, Dinas Kehutanan Sumberdaya Mineral dan Energi Kabupaten Sumedang, dan BPS Kabupaten Sumedang.

\section{Analisis Data}

Untuk memahami dinamika rantai nilai dari mebel kayu mahoni Jepara dilakukan identifikasi para pelaku yang terlibat serta menganalisis distribusi nilai tambah. Dari hasil analisis tersebut selanjutnya dibangun berbagai skenario kebijakan dengan menggunakan model dinamik (dynamic modelling).

\section{Identifikasi para pelaku (aktor)}

Identifikasi aktor sepanjang rantai nilai mebel dilakukan melalui penelusuran dan keterkaitan ke belakang dimulai dari eksportir dan pengecer/toko domestik sampai ke penanam mahoni yaitu petani dan Perhutani. Selanjutnya memetakan hubungan antar aktor yang terlibat dalam sebuah diagram.

\section{Analisis distribusi nilai tambah}

Distribusi nilai tambah untuk masing-masing pelaku sepanjang rantai nilai mebel mahoni Jepara diperoleh melalui analisis yang dilakukan dengan tahapan sebagai berikut:

a. Analisis aliran produk di setiap pelaku antara lain meliputi: a) nilai output kotor, b) nilai output bersih, c) aliran fisik barang, dan d) tujuan pemasaraan.

b. Langkah berikutnya adalah analisis nilai tambah dan distribusi nilai tambah. Margin 
keuntungan yang diterima oleh masing-masing aktor (lembaga pemasaran) dirumuskan sebagai berikut:

$\pi=\mathrm{P}_{\mathrm{s}}-\mathrm{P}_{\mathrm{b}}-\mathrm{C}$

Dimana:

$\pi=$ Keuntungan yang diterima oleh setiap pelaku (aktor)

$\mathrm{P}_{\mathrm{s}}=$ Harga jual produk di setiap pelaku

$\mathrm{P}_{\mathrm{b}}=$ Harga beli bahan baku di setiap pelaku

$\mathrm{C}=$ Biaya produksi dan pemasaran pada setiap pelaku

Distribusi margin keuntungan dihitung berdasarkan persentase keuntungan masingmasing lembaga pemasaran terhadap keuntungan total seluruh lembaga pemasaran

\section{Analisis sistem (pemodelan)}

Untuk mengetahui dinamika dari rantai nilai mebel mahoni Jepara, tahap analisis berikutnya adalah analisis sistem dan simulasi dengan menggunakan perangkat lunak Stella 8. Adapun langkah-langkah yang digunakan dalam analisis sistem adalah (Purnomo 2005, 2006; Grant etal. 1997):

Identifikasi isu, tujuan dan batasan

Tujuan dari tahap ini adalah mengidentifikasi isu-isu permasalahan serta menentukan tujuan dari pemodelan yang dikembangkan. Sesuai dengan permasalahan dan tujuan dari penelitian, maka penyusunan model ditujukan untuk mendorong upaya mempertahankan kelangsungan industri mebel.

Perumusan model konseptual dan spesifikasi model kuantitatif

Tahapan ini bertujuan untuk membangun pemahaman terhadap sistem yang diamati, kemudian dituangkan dalam sebuah konsep untuk mendapatkan gambaran secara menyeluruh tentang model yang dibuat. Tahap selanjutnya adalah membentuk model kuantitatif dari konsep model yang telah ditetapkan, yang terbagi menjadi beberapa sub model

Luas hutan mahoni:

Analisis luas tanaman mahoni Perhutani diproyeksikan sebagai berikut:

$$
\mathrm{A}_{\mathrm{p}, \mathrm{t}+1}=\mathrm{A}_{\mathrm{p}, \mathrm{t}}+\mathrm{R}_{\mathrm{p}}+\mathrm{O}_{\mathrm{p}} \mathrm{M}_{\mathrm{p}}-\mathrm{L}_{\mathrm{p}}-\mathrm{Ia}_{\mathrm{p}}
$$

Dimana:

$\mathrm{A}_{\mathrm{p}, \mathrm{t}+1}=$ Luas areal pada masing-masing kelas umur setelah $\mathrm{t}+1$ di Perhutani

$\mathrm{A}_{\mathrm{p}, \mathrm{t}}=$ Luas areal pada masing-masing kelas umur pada tahun ke $t$ di Perhutani

$\mathrm{R}_{\mathrm{p}}=$ Luas areal yang masuk ke dalam kelas umur tertentu (karena adanya penanaman) di Perhutani

$\mathrm{O}_{\mathrm{p}}=$ Luas areal yang pindah dari kelas umur tertentu ke kelas umur yang lebih besar karena adanya pertumbuhan di Perhutani

$\mathrm{M}_{\mathrm{p}}=$ Luas areal yang keluar dari kelas umur tertentu dimana tegakannya mati karena kebakaran dan bencana alam di Perhutani

$\mathrm{L}_{\mathrm{p}}=$ Luas areal yang dipanen di Perhutani

$\mathrm{IA}_{\mathrm{p}}=$ Luas areal yang mengalami gangguan seperti kegiatan penebangan ilegal, penyerobotan lahan, penggembalaan liar di Perhutani

Sedangkan proyeksi luas tanaman mahoni rakyat adalah sebagai berikut:

$\mathrm{A}_{\mathrm{r}, \mathrm{t}+1}=\mathrm{A}_{\mathrm{t}, \mathrm{t}}+\mathrm{R}_{\mathrm{r}}-\mathrm{L}_{\mathrm{r}}$

Dimana:

$\mathrm{A}_{\mathrm{t}, \mathrm{t}+1}=$ Luas areal tanaman mahoni setelah $\mathrm{t}+1$ di hutan rakyat $(\mathrm{ha})$

Distribusi nilai tambah pada rantai ...... (Nunung Parlinah, Herry Purnomo and Bramasto Nugroho) 


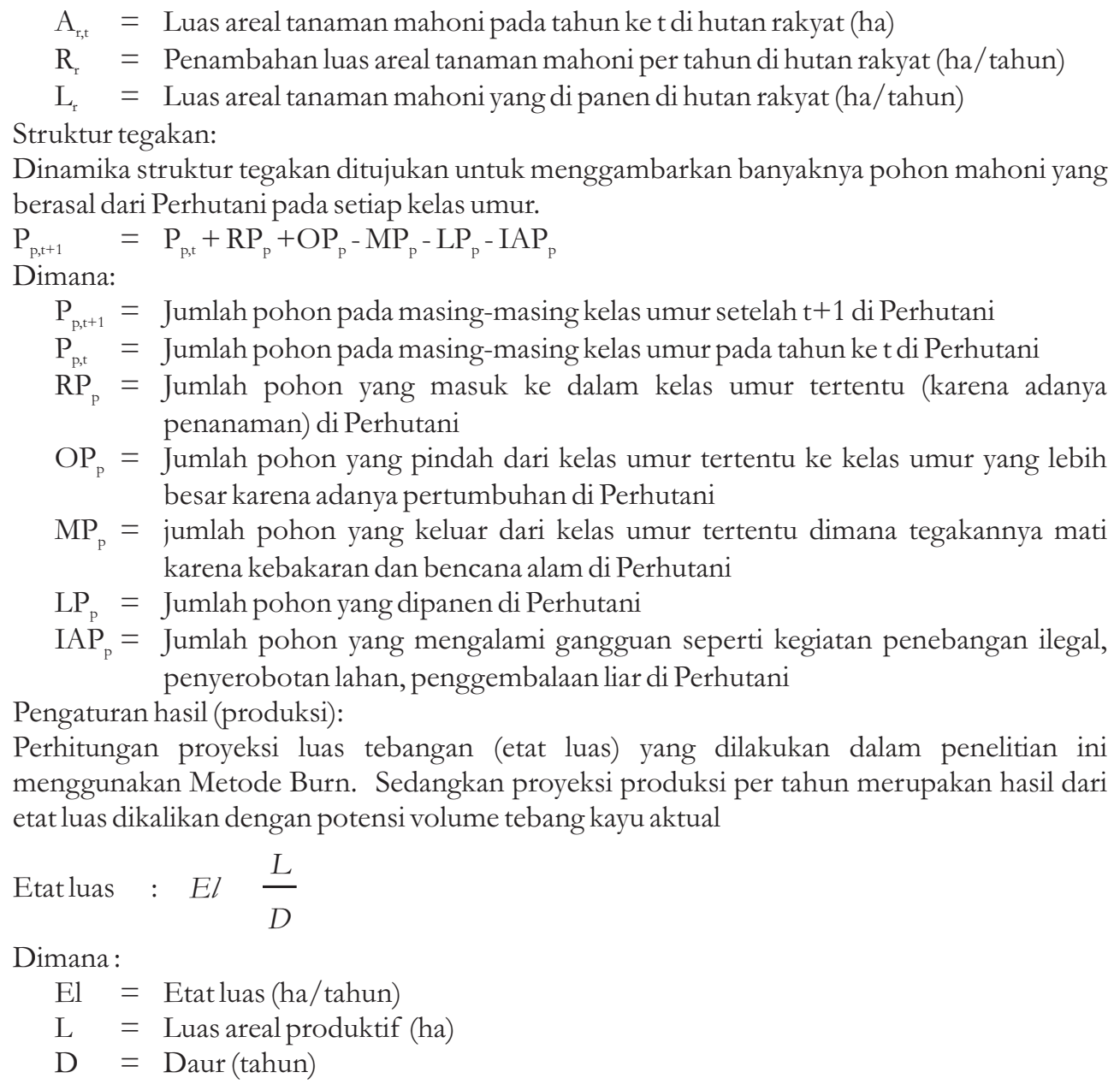

Sedangkan proyeksi produksi kayu mahoni yang berasal dari hutan rakyat dihitung sebagai berikut:

$\mathrm{V}_{\mathrm{r}, \mathrm{t}+1}=\mathrm{V}_{\mathrm{r}, \mathrm{t}}+\left(\mathrm{VP}_{\mathrm{r}} \mathrm{x} \mathrm{L}_{\mathrm{r}}\right)$

Dimana:

$\mathrm{V}_{\mathrm{r}, \mathrm{t}+1}=$ Volume produksi kayu mahoni rakyat setelah $\mathrm{t}+1\left(\mathrm{~m}^{3}\right)$

$\mathrm{V}_{\mathrm{r}, \mathrm{t}}=$ Volume produksi kayu mahoni rakyat pada tahun ke- $\mathrm{t}\left(\mathrm{m}^{3}\right)$

$\mathrm{VP}_{\mathrm{r}}=$ Potensi produksi kayu mahoni rakyat $\left(\mathrm{m}^{3} / \mathrm{ha} /\right.$ tahun $)$

$\mathrm{L}_{\mathrm{r}} \quad=$ Luas areal tanaman mahoni yang di panen di hutan rakyat (ha/tahun)

Aliran fisik dari kayu (perdagangan kayu dan mebel mahoni) adalah:

$\mathrm{V}_{\text {ind, },+1}=\mathrm{V}_{\text {ind, },}+\mathrm{V}_{\mathrm{i}}-\left((1-\mathrm{RD}) \times \mathrm{V}_{\mathrm{i}}\right)$

Dimana:

$\mathrm{V}_{\text {ind,t+1}}=$ Volume kayu setiap tahap produksi setelah $\mathrm{t}+1\left(\mathrm{~m}^{3}\right)$

$\mathrm{V}_{\text {ind, }}=$ Volume kayu setiap tahap produksi pada tahun ke-t $\left(\mathrm{m}^{3}\right)$ 


$$
\begin{aligned}
& \mathrm{V}_{\mathrm{i}}=\text { Volume kayu yang masuk ke setiap tahap produksi }\left(\mathrm{m}^{3}\right) \\
& \mathrm{RD}=\text { Rendemen di setiap tahap produksi }
\end{aligned}
$$

\section{Evaluasi model}

Tujuan dari tahap ini adalah mengetahui keterandalan model yang dibuat dalam menggambarkan keadaan yang sebenarnya. Proses pengujian dilakukan dengan mengamati kelogisan model dan membandingkan dengan dunia nyata atau model andal yang serupa.

Penggunaan model

Kegiatan pertama yang dilakukan adalah membuat daftar semua alternatif (skenario) dari model yang telah dikembangkan. Berdasarkan hasil yang diperoleh, selanjutnya menganalisis skenario dan membuat urutan prioritas dari skenario yang terpilih. Tahap akhir adalah merumuskan skenario tersebut menjadi sebuah alternatif atau pilihan kebijakan.

\section{HASIL DAN PEMBAHASAN}

\section{A. Identifikasi Aktor}

Para pelaku yang terlibat dalam usaha mebel kayu mahoni Jepara antara lain petani penanam kayu, Perhutani, pedagang kayu di Jepara dan luar Jepara, pemilik penggergajian, pengrajin, pemilik jasa finishing, pengecer atau toko domestik, eksportir dan pembeli global. Selain membeli mebel setengah jadi dari pengrajin, beberapa eksportir dan toko domestik juga melakukan kegiatan finishing mebel sendiri sebelum dijual kembali.

Berdasarkan aliran informasi pemesanan mebel, proses produksi mebel dapat dikategorikan menjadi (1) produksi mebel berdasarkan pesanan pembeli dan (2) produksi mebel tidak berdasarkan pesanan. Dari kedua kategori tersebut, yang banyak terjadi di Jepara adalah produksi mebel berdasarkan pesanan.

Pada produksi mebel berdasarkan pesanan, aliran informasi pemesanan dapat berasal dari pembeli luar negeri dan pembeli dalam negeri (Gambar 2 dan 3). Desain dan spesifikasi dari mebel dibuat sesuai dengan keinginan pembeli (bersifat buyer driven). Pembeli luar negeri umumnya memesan mebel ke eksportir, yang selanjutnya pesanan tersebut disubkontrakkan kembali ke pengrajin. Sedangkan produksi mebel yang tidak berdasarkan pesanan, para pengrajin membuat mebel dengan desain yang sudah umum untuk memudahkan dalam penjualan (Gambar 4).

\section{B. Distribusi Nilai Tambah}

Aliran produk mebel terbagi menjadi aliran produk untuk pasar domestik dan aliran produk untuk pasar ekspor. Mebel yang diproduksi untuk kedua pasar tersebut umumnya memiliki grade yang berbeda dimana perbedaan kualitas terjadi mulai dari awal pembuatan mebel, sehingga ukuran dan kualitas bahan baku yang digunakan juga berbeda. Mebel untuk pasar domestik biasanya memiliki grade yang lebih rendah dibandingkan mebel untuk pasar ekspor.

Hasil penelitian menunjukkan bahwa besarnya pertambahan nilai total per $\mathrm{m}^{3}$ bahan baku pada pasar domestik adalah Rp 1.477.000 yang terdistribusi secara tidak merata seperti yang tersaji pada Tabel 1. Pelaku yang banyak memperoleh nilai tambah adalah retailer yang sekaligus melakukan finishing sendiri. Sedangkan yang paling kecil memperoleh nilai tambah

Distribusi nilai tambah pada rantai ...... (Nunung Parlinah, Herry Purnomo and Bramasto Nugroho) 
adalah penggergajian. Tingginya nilai tambah yang diperoleh pengecer domestik selain berasal dari proses pemasaran dan penguasaan informasi pasar, juga berasal dari keuntungan yang diperoleh pada proses finishing.

Besarnya pertambahan nilai total per $\mathrm{m}^{3}$ bahan baku untuk pasar ekspor dengan bahan baku berasal dari kayu rakyat adalah Rp 1.938.000, dan sebesar Rp. 2.300.000 untuk bahan baku yang berasal dari Perhutani. Dari kedua sumber bahan baku tersebut, nilai tambah terbesar diperoleh eksportir dan yang terkecil diperoleh penggergajian (Tabel 2 dan 3). Proses finishing pada pasar ekspor umumnya dikerjakan oleh para eksportir. Penguasaan informasi tentang pembeli dan keuntungan yang diperoleh pada proses finishing, membuat bagian keuntungan yang diperoleh eksportir lebih tinggi dibanding aktor yang lain.

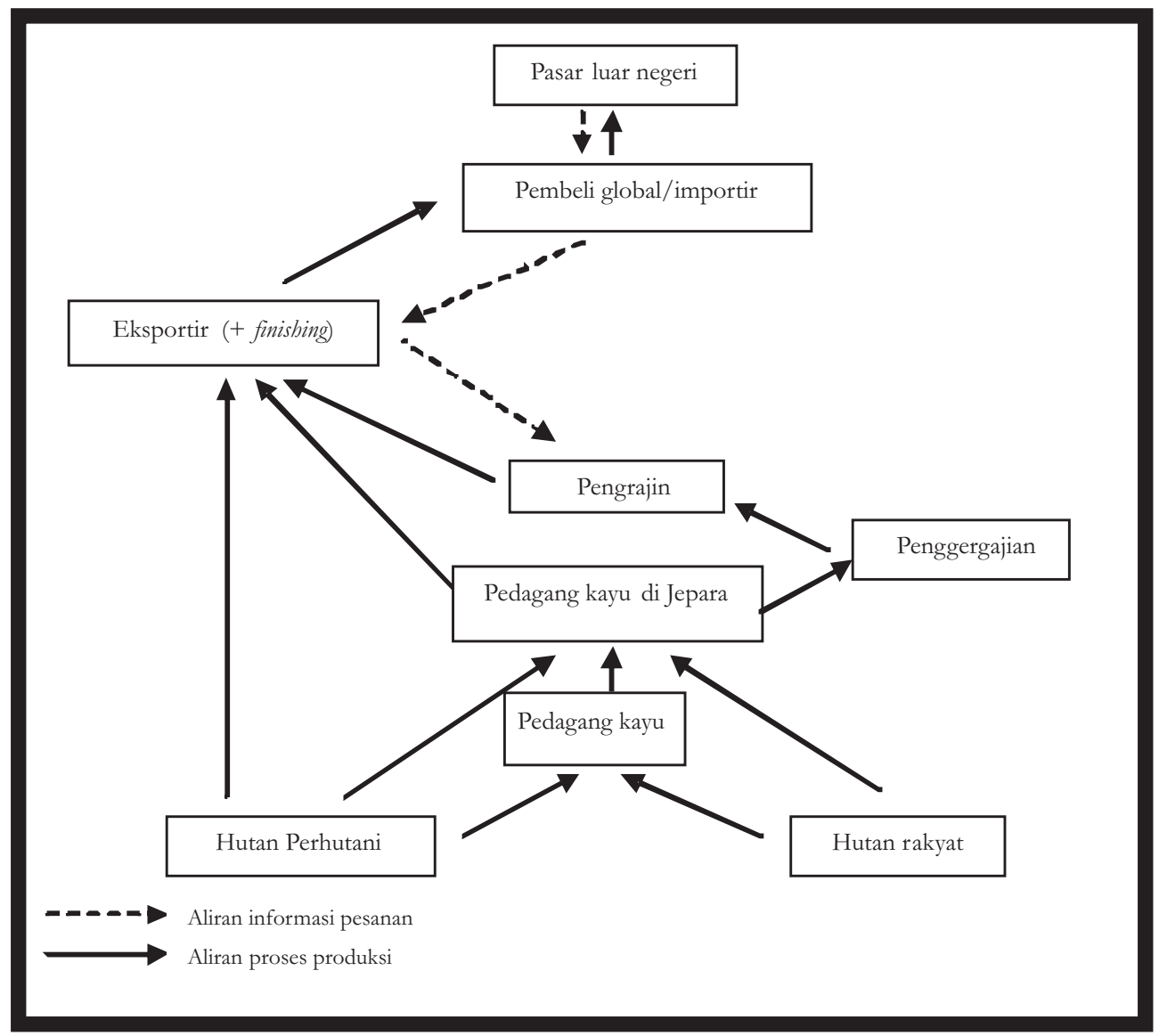

Gambar 2. Produksi mebel pesanan untuk pasar luar negeri.

Figure 2. Production of furniture ordered for foreign markets 


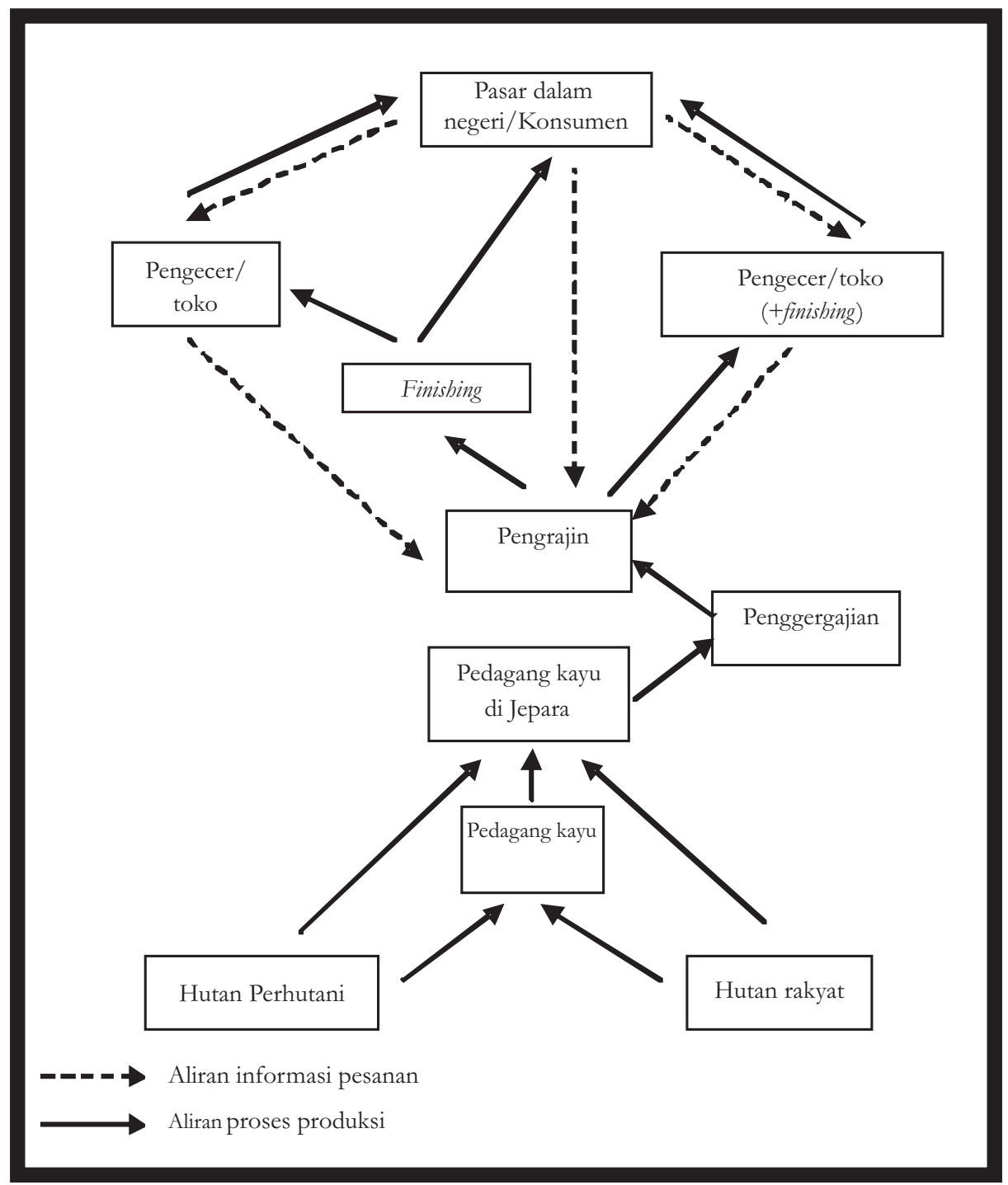

Gambar 3. Produksi mebel pesanan untuk pasar dalam negeri.

Figure 3. Production of furniture ordered for domestic markets

\section{Analisis Sistem dan Skenario Kebijakan}

Bisnis di bidang mebel merupakan bisnis yang besar dan melibatkan banyak pekerja seperti tersaji pada Gambar 5.

Tujuan pembuatan skenario dimaksudkan untuk mempertahankan kelangsungan industri mebel. Untuk mengelola kelangsungan bisnis mebel, paling tidak terdapat dua langkah yang diperlukan yaitu (1) memberikan nilai tambah yang lebih tinggi kepada penanam kayu dan industri mebel skala kecil dan menengah, serta (2) melakukan investasi penanaman pohon (Purnomo, 2006). Sedangkan menurut Kaplinsky dan Readman (2001); Kaplinsky

Distribusi nilai tambah pada rantai ...... (Nunung Parlinah, Herry Purnomo and Bramasto Nugroho) 


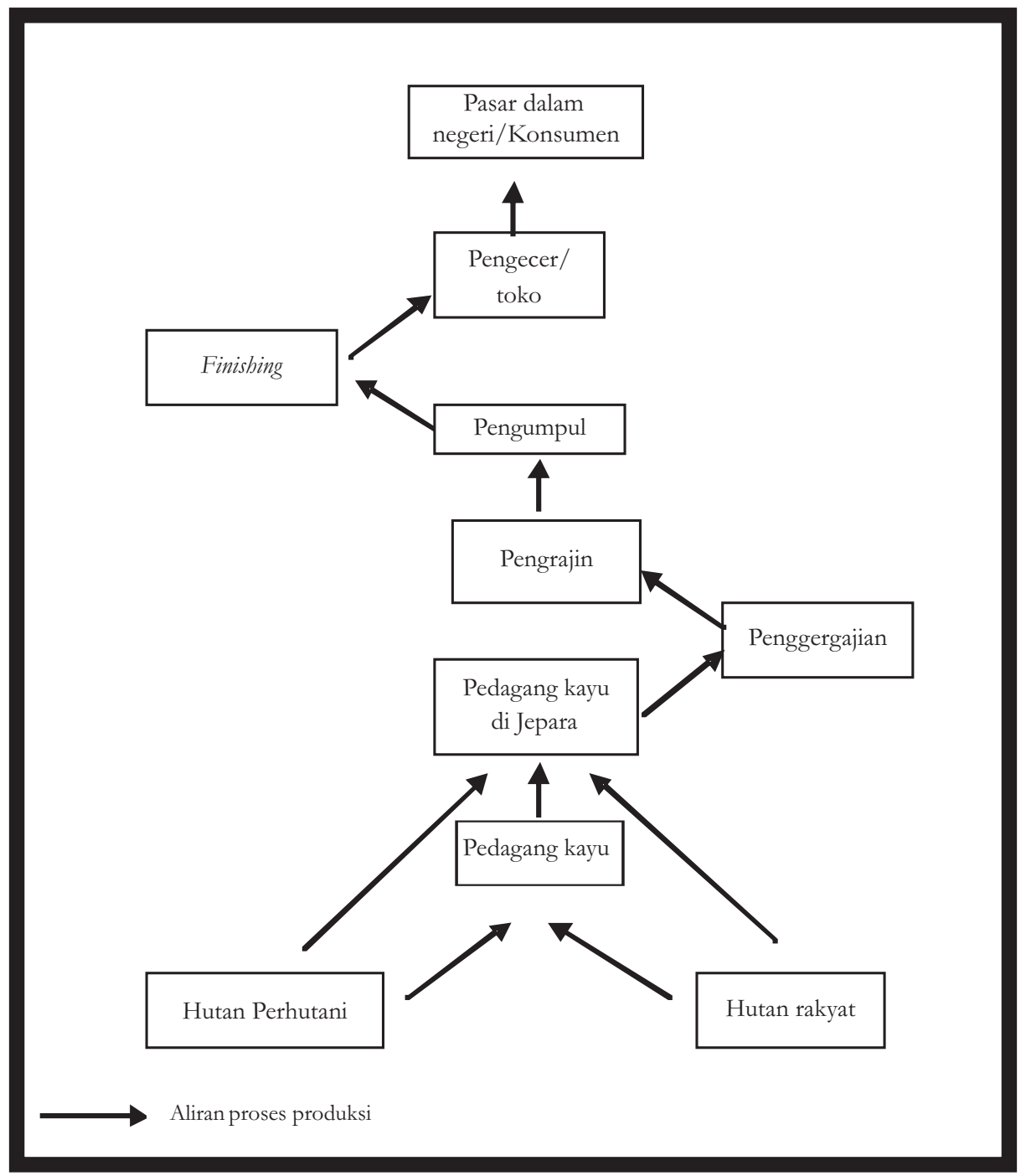

Gambar 4. Produksi mebel dengan desain umum.

Figure 4. Production of furniture with common design.

dan Morris (2000), untuk mempertahankan kelangsungan pendapatan terletak pada kemampuan upgrading proses (meningkatkan efisiensi dalam proses internal), upgrading produk (mengenalkan produk baru atau meningkatkan produk lama lebih baik), upgrading fungsi (mengubah kegiatan yang dikerjakan dalam perusahaan) dan upgrading rantai (chain) dengan berpindah dari satu rantai nilai ke rantai nilai yang lain.

Dalam penelitian ini, beberapa skenario yang dibuat adalah:

1. peningkatan efisiensi produksi pada proses penggergajian dan proses pembuatan mebel di tingkat pengrajin 
2. peningkatan volume tebang kayu Perhutani melalui penanaman lahan kosong milik Perhutani

3. penerapan fair trade melalui pengurangan biaya transaksi

Tabel 1. Distribusi nilai tambah kayu mahoni untuk pasar domestik

Table 1. Value added distribution of mahogany for domestic market

\begin{tabular}{|c|c|c|c|c|c|c|c|c|}
\hline \multirow[t]{2}{*}{$\begin{array}{l}\text { Aktor } \\
\text { Actor }\end{array}$} & \multirow[t]{2}{*}{$\begin{array}{l}\text { Rendemen } \\
\text { Product flow } \\
\text { efficiency (\%) }\end{array}$} & \multirow[t]{2}{*}{$\begin{array}{c}\text { Produk } \\
\text { tinggal } \\
\text { Remaining } \\
\text { product }\left(\mathrm{m}^{3}\right)\end{array}$} & \multirow[t]{2}{*}{$\begin{array}{l}\text { Nilai Output } \\
\text { Output value } \\
\text { (Rp x 1000) }\end{array}$} & \multirow[t]{2}{*}{$\begin{array}{c}\text { Biaya input } \\
\text { Input cost } \\
\text { (Rp x 1000 }\end{array}$} & \multicolumn{2}{|c|}{$\begin{array}{c}\text { Distribusi nilai } \\
\text { tambah per } \mathrm{m}^{3} \\
\text { bahan baku } \\
\text { Value added } \\
\text { distribution per } \mathrm{m}^{3} \\
\text { raw material }\end{array}$} & \multicolumn{2}{|c|}{$\begin{array}{c}\text { Distribusi nilai } \\
\text { tambah per } \mathrm{m}^{3} \\
\text { produk } \\
\text { Value added } \\
\text { distribution per } \mathrm{m}^{3} \\
\text { product }\end{array}$} \\
\hline & & & & & $\operatorname{Rp}(x$ 1000) & $\%$ & $\operatorname{Rp}(\mathrm{x} 1000)$ & $\%$ \\
\hline $\begin{array}{l}\text { Petani ky Sumedang } \\
\text { Farmer in Sumedang }\end{array}$ & 100 & 1,00 & 274 & 165 & 109 & 7,38 & 109 & 2,75 \\
\hline $\begin{array}{l}\text { Pedagang Sumedang } \\
\text { Log trader in Sumedang }\end{array}$ & 100 & 1,00 & 450 & 395 & 55 & 3,72 & 55 & 1,39 \\
\hline $\begin{array}{l}\text { Pedagang ky Jepara } \\
\text { Log trader in Jepara }\end{array}$ & 100 & 1,00 & 600 & 464 & 136 & 9,21 & 136 & 3,43 \\
\hline $\begin{array}{l}\text { Penggergajian } \\
\text { Sawmill owners }\end{array}$ & 58 & 0,58 & 70 & 37 & 33 & 2,23 & 57 & 1,43 \\
\hline $\begin{array}{l}\text { Pengrajin psr dmstk } \\
\text { Domestic furniture } \\
\text { producers }\end{array}$ & 57 & 0,33 & 1.888 & 1.480 & 408 & 27,62 & 1.236 & 31,16 \\
\hline $\begin{array}{l}\text { Retlr dmstk }+ \text { finishing } \\
\text { Domestic retailer }+ \\
\text { finishing }\end{array}$ & 95 & 0,31 & 3.680 & 2.944 & 736 & 49,83 & 2.374 & 59,84 \\
\hline Total & & & 6.962 & 5.485 & 1.477 & $\begin{array}{r}100,0 \\
0 \\
\end{array}$ & 3.967 & $\begin{array}{r}100,0 \\
0 \\
\end{array}$ \\
\hline
\end{tabular}

Tabel 2. Distribusi nilai tambah kayu mahoni untuk pasar ekspor dari kayu rakyat

Table 2. Value added distribution of mahogany from community forest for export market

\begin{tabular}{|c|c|c|c|c|c|c|c|c|}
\hline \multirow[t]{2}{*}{$\begin{array}{l}\text { Aktor } \\
\text { Actor }\end{array}$} & \multirow[t]{2}{*}{$\begin{array}{l}\text { Rendemen } \\
\text { Product flow } \\
\text { efficiency (\%) }\end{array}$} & \multirow[t]{2}{*}{$\begin{array}{c}\text { Produk } \\
\text { tinggal } \\
\text { Remaining } \\
\text { product }\left(\mathrm{m}^{3}\right)\end{array}$} & \multirow[t]{2}{*}{$\begin{array}{l}\text { Nilai Output } \\
\text { Output value } \\
\text { (Rp x 1000) }\end{array}$} & \multirow[t]{2}{*}{$=\begin{array}{c}\text { Biaya input } \\
\text { Input cost } \\
(\operatorname{Rp} \times 1000)\end{array}$} & \multicolumn{2}{|c|}{$\begin{array}{l}\text { Distribusi nilai } \\
\text { tambah per } \mathrm{m}^{3} \\
\text { bahan baku } \\
\text { Value added } \\
\text { distribution per m }{ }^{3} \\
\text { raw material } \\
\end{array}$} & \multicolumn{2}{|c|}{$\begin{array}{c}\text { Distribusi nilai } \\
\text { tambah per } \mathrm{m}^{3} \\
\text { produk } \\
\text { Value added } \\
\text { distribution per } \mathrm{m}^{3} \\
\text { product } \\
\end{array}$} \\
\hline & & & & & $\operatorname{Rp}(x$ 1000) & $\%$ & $\operatorname{Rp}(x 1000)$ & $\%$ \\
\hline $\begin{array}{l}\text { Petani ky Sumedang } \\
\text { Farmer in Sumedang }\end{array}$ & 100 & 1,00 & 549 & 330 & 219 & 11,30 & 219 & 4,69 \\
\hline $\begin{array}{l}\text { Pedagang Sumedang } \\
\text { Log trader in Sumedang }\end{array}$ & 100 & 1,00 & 800 & 702 & 98 & 5,06 & 98 & 2,10 \\
\hline $\begin{array}{l}\text { Pedagang ky Jepara } \\
\text { Log trader in Jepara }\end{array}$ & 100 & 1,00 & 1.150 & 827 & 323 & 16,67 & 323 & 6,92 \\
\hline $\begin{array}{l}\text { Penggergaiian } \\
\text { Sawmill owners }\end{array}$ & 58 & 0,58 & 70 & 37 & 33 & 1,70 & 57 & 1,22 \\
\hline $\begin{array}{l}\text { Pengrajin psr eksp } \\
\text { Export furniture producer }\end{array}$ & 57 & 0,33 & 2.360 & 1.808 & 552 & 28,48 & 1.673 & 35,82 \\
\hline $\begin{array}{l}\text { Eksportir + finishing } \\
\text { Exporter + finishing }\end{array}$ & 95 & 0,31 & 4.973 & 4.260 & 713 & 36,79 & 2.300 & 49,25 \\
\hline Total & & & 9.902 & 7.964 & 1.938 & $\begin{array}{r}100,0 \\
0\end{array}$ & 4.670 & $\begin{array}{r}100,0 \\
0\end{array}$ \\
\hline
\end{tabular}

Distribusi nilai tambah pada rantai ...... (Nunung Parlinah, Herry Purnomo and Bramasto Nugroho) 
Tabel 3. Distribusi nilai tambah kayu mahoni untuk pasar ekspor dari kayu Perhutani Table 3. Value added distribution of mahogany from Perbutani for export market

\begin{tabular}{|c|c|c|c|c|c|c|c|c|}
\hline \multirow[t]{2}{*}{$\begin{array}{l}\text { Aktor } \\
\text { Actor }\end{array}$} & \multirow[t]{2}{*}{$\begin{array}{l}\text { Rendemen } \\
\text { Product flow } \\
\text { efficiency (\%) }\end{array}$} & \multirow[t]{2}{*}{$\begin{array}{c}\text { Produk } \\
\text { tinggal } \\
\text { Remaining } \\
\text { product }\left(\mathrm{m}^{3}\right)\end{array}$} & \multirow[t]{2}{*}{$\begin{array}{l}\text { Nilai Output } \\
\text { Output value } \\
\text { (Rp x 1000) }\end{array}$} & \multirow[t]{2}{*}{$\begin{array}{c}\text { Biaya input } \\
\text { Input cost } \\
(\operatorname{Rp} \times 1000)\end{array}$} & \multicolumn{2}{|c|}{$\begin{array}{c}\text { Distribusi nilai } \\
\text { tambah per } \mathrm{m}^{3} \\
\text { bahan baku } \\
\text { Value added } \\
\text { distribution per } \mathrm{m}^{3} \\
\text { raw material }\end{array}$} & \multicolumn{2}{|c|}{$\begin{array}{c}\text { Distribusi nilai } \\
\text { tambah per } \mathrm{m}^{3} \\
\text { produk } \\
\text { Value added } \\
\text { distribution per } \mathrm{m}^{3} \\
\text { product }\end{array}$} \\
\hline & & & & & $\operatorname{Rp}(x$ 1000) & $\%$ & $\operatorname{Rp}(x$ 1000) & $\%$ \\
\hline $\begin{array}{l}\text { Perhutani } \\
\text { Perbutani }\end{array}$ & 100 & 1,00 & 1.391 & 753 & 638 & 27,74 & 638 & 12,68 \\
\hline $\begin{array}{l}\text { Pedagang ky Jepara } \\
\text { Log trader in Jepara }\end{array}$ & 100 & 1,00 & 1.500 & 1.136 & 364 & 15,83 & 364 & 7,23 \\
\hline $\begin{array}{l}\text { Penggergajian } \\
\text { Sawmill owners }\end{array}$ & 58 & 0,58 & 70 & 37 & 33 & 1,43 & 57 & 1,13 \\
\hline $\begin{array}{l}\text { Pengrajin psr eksp } \\
\text { Export furniture producer }\end{array}$ & 57 & 0,33 & 2.360 & 1.808 & 552 & 24,00 & 1.673 & 33,24 \\
\hline $\begin{array}{l}\text { Eksportir + finishing } \\
\text { Exporter }+ \text { finishing }\end{array}$ & 95 & 0,31 & 4.973 & 4.260 & 713 & 31,00 & 2.300 & 45,71 \\
\hline Total & & & 10.294 & 7.994 & 2.300 & $\begin{array}{r}100,0 \\
0\end{array}$ & 5.032 & $\begin{array}{r}100,0 \\
0\end{array}$ \\
\hline
\end{tabular}

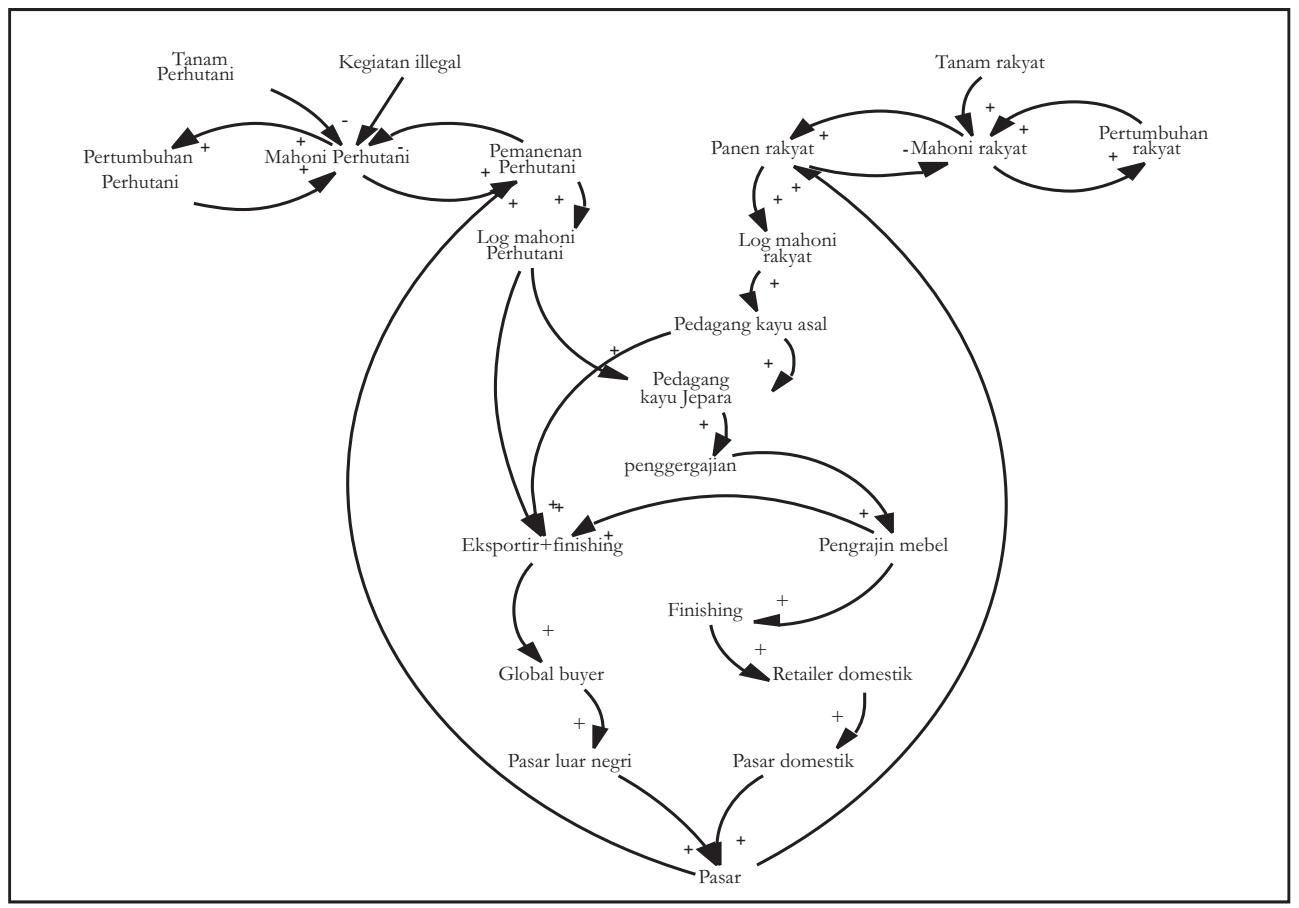

Gambar 5. Diagram sebab akibat usaha mebel kayu mahoni

Figure 5. Causal loop diagram of mahogany furniture business 


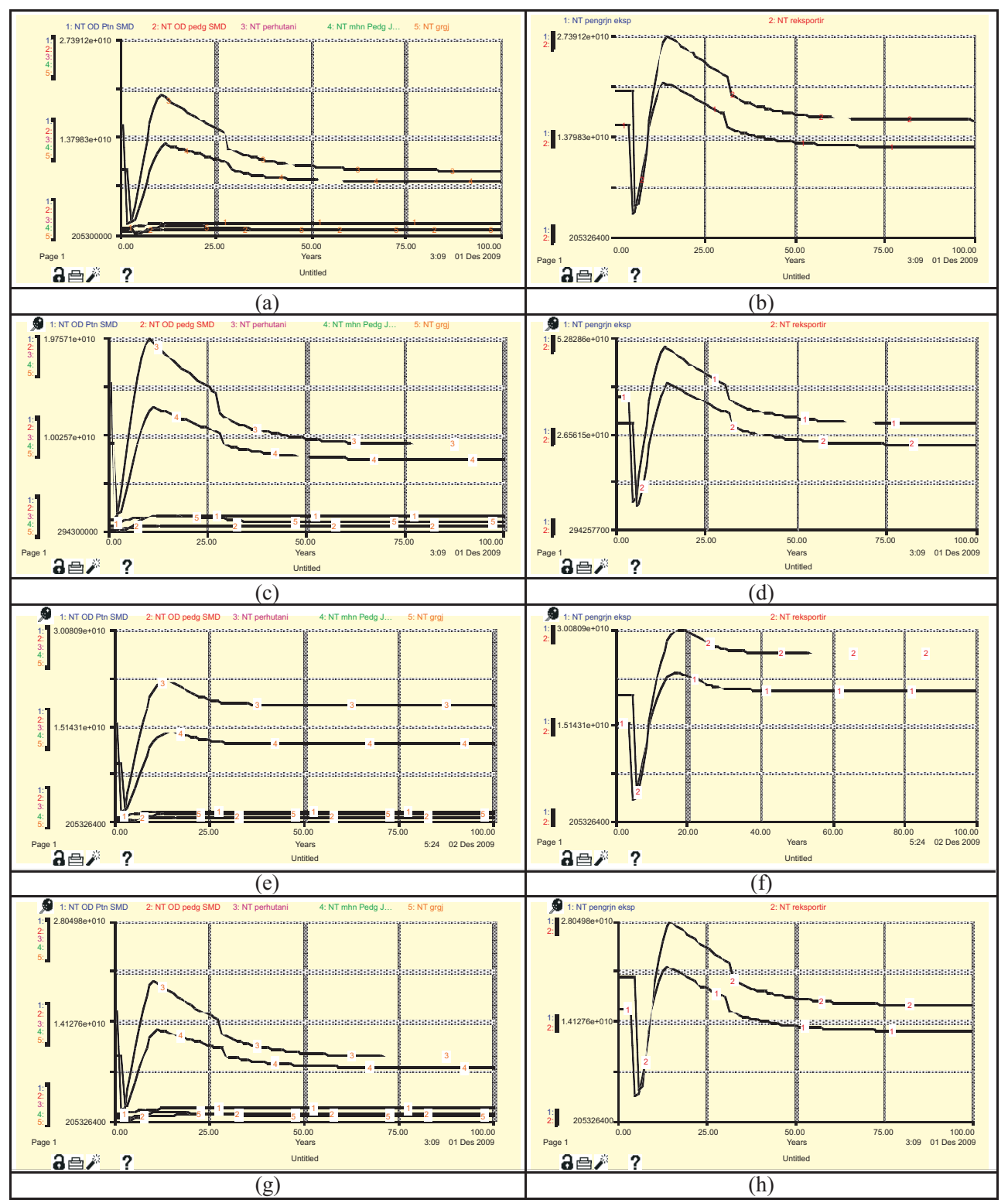

Gambar 6. Dinamika distribusi nilai tambah pasar ekspor (a, b) simulasi dasar, (c, d) skenario efisiensi produksi, (e, f) skenario penanaman, (g, h) skenario fair trade

Figure 6. Dynamics of value added distributionfor export markets: $(a, b)$ basic simulation, $(c, d)$ production efficiency scenario, $(e, f)$ land investment scenario, $(g, b)$ fair trade scenario 


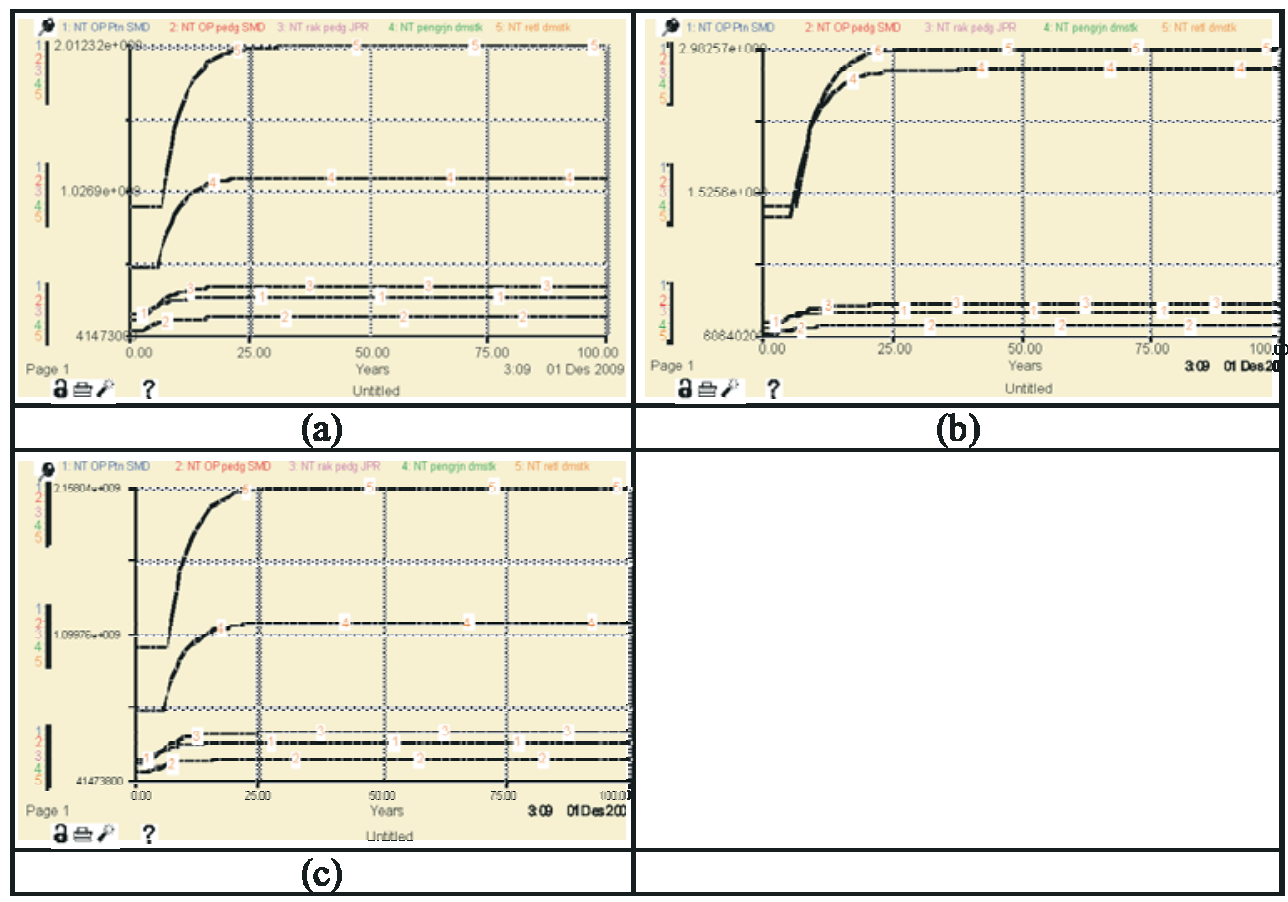

Gambar 7. Dinamika distribusi nilai tambah pasar domestik (a) simulasi dasar, (b) skenario efisiensi produksi, (c) skenario fair trade

Figure 7. Dynamics of value added distribution for domestic market: (a) basic simulation, (b) production efficiency scenario, (c) fair trade scenario

Hasil simulasi dasar serta simulasi dari ketiga skenario tersebut seperti tersaji dalam Gambar 6 dan 7.

\section{Peningkatan efisiensi produksi}

Skenario peningkatan efisiensi produksi dilakukan pada proses penggergajian sebesar $70 \%$ dan proses pembuatan mebel di tingkat pengrajin sebesar $70 \%$. Selama tahun simulasi menunjukkan terjadinya peningkatan pertambahan nilai baik pada pasar ekspor maupun pada pasar domestik (Gambar 6 dan 7). Pertambahan nilai pada pasar domestik untuk penggergajian meningkat 43,31\% dibanding pada simulasi dasar (meningkat sebesar Rp 39,57 juta). Peningkatan pertambahan nilai di tingkat pengrajin sebesar 148,20\% dari simulasi dasar, dengan nilai tambah pada akhir simulasi sebesar Rp. 2,76 milyar.

Pada pasar ekspor, nilai tambah kumulatif di akhir simulasi skenario efisiensi mengalami peningkatan sebesar 52,15\% dibandingkan dengan simulasi dasar. Nilai tambah kumulatif akhir tahun simulasi skenario efisiensi ini sebesar Rp 73,21 milyar. Namun apabila dibandingkan dengan awal tahun simulasi, pada skenario ini masih terjadi penurunan nilai tambah hampir di seluruh pelaku kecuali petani dan pedagang kayu di Sumedang.

\section{Peningkatan volume produksi dengan penanaman laban kosong}

Skenario kedua merupakan upaya peningkatan volume kayu yang ditebang melalui penanaman lahan kosong di areal Perhutani KPH Pati sebesar 25\% dari lahan kosong yang 
diperuntukkan untuk tanaman mahoni. Sedangkan simulasi penanaman lahan kosong di hutan rakyat tidak dilakukan karena produksi kayu dari hutan rakyat selama ini sudah meningkat.

Nilai tambah kumulatif pada akhir simulasi yang diterima para pelaku pasar ekspor meningkat dari Rp 49,01 milyar pada simulasi dasar menjadi Rp 81,20 milyar. Adapun besarnya distribusi nilai tambah para pelaku pada akhir tahun simulasi adalah 32,44\% eksportir, 25,11\% pengrajin, 22,58\% Perhutani, $15,15 \%$ pedagang kayu Jepara, 2,20\% petani, $1,52 \%$ industri penggergajian dan $0,99 \%$ pedagang kayu Sumedang.

\section{Penerapan fair trade melalui pengurangan biaya transaksi}

Skenario ketiga yaitu fair trade melalui pengurangan (menghilangkan) biaya transaksi. Adapun biaya transaksi yang dapat teridentifikasi di pedagang kayu Sumedang rata-rata Rp 10.500 per $\mathrm{m}^{3}$, pedagang kayu Jepara rata-rata Rp. 6.250 per $\mathrm{m}^{3}$, pengrajin rata-rata Rp17.500 per $\mathrm{m}^{3}$, pengecer (toko) rata-rata $\mathrm{Rp} 53.300$ per $\mathrm{m}^{3}$ dan eksportir rata-rata $\mathrm{Rp} 13.700$ per $\mathrm{m}^{3}$. Biaya transaksi tersebut dapat dikategorikan dalam dua kelompok yaitu yang bersifat tetap seperti yang terjadi di tingkat pedagang kayu dan yang bersifat biaya variabel (tergantung dari jumlah unit yang dipertukarkan) seperti yang terjadi di tingkat pengrajin.

Pada pasar domestik, terjadi peningkatan nilai tambah di akhir tahun simulasi masingmasing sebesar 12,21\% untuk pedagang kayu di Sumedang, 0,56\% pedagang kayu di Jepara, $4,91 \%$ pengrajin pasar domestik, dan $7,24 \%$ pengecer/toko. Peningkatkan nilai tambah kumulatif untuk pasar domestik pada akhir simulasi sebesar 5,47\% dengan nilai tambah yang diterima menjadi Rp 4,25 milyar.

Untuk pasar ekspor, peningkatan nilai tambah yang diterima oleh pedagang kayu di Sumedang, pedagang kayu di Jepara, pengrajin untuk pasar ekspor dan eksportir pada akhir tahun simulasi masing-masing sebesar $12,21 \%, 0,46 \%, 2,85 \%$ dan 2,40\%. Besarnya peningkatan nilai tambah total pada skenario ini adalah 1,81\% dibandingkan dengan simulasi dasar dengan nilai tambah total yang diterima menjadi Rp 48,98 milyar.

Dari ketiga skenario di atas, skenario yang paling besar memberikan nilai tambah pada akhir tahun simulasi untuk pasar domestik adalah meningkatkan efisiensi produksi, diikuti dengan fair trade. Sedangkan untuk pasar ekspor, skenario yang paling besar memberikan nilai tambah pada akhir tahun simulasi secara berturut-turut adalah penanaman lahan kosong di areal Perhutani, peningkatan efisiensi dan fair trade (Tabel 4).

Tabel 4. Nilai tambah pada akhir tahun simulasi dengan berbagai skenario (x RP 1 Juta) Table 4. Value added at the end of the simulation with different scenarios ( $x$ million IDR)

\begin{tabular}{llc}
\hline \multicolumn{1}{c}{$\begin{array}{c}\text { Skenario } \\
\text { (Scenario) }\end{array}$} & $\begin{array}{c}\text { NT total domestik } \\
\text { (Total value added in } \\
\text { domestic marke) }\end{array}$ & $\begin{array}{c}\text { NT total ekspor } \\
\text { (Total value added in } \\
\text { export market) }\end{array}$ \\
\hline $\begin{array}{l}\text { Simulasi dasar } \\
\text { Basic simulation }\end{array}$ & $4.037,550$ & $48.116,691$ \\
$\begin{array}{l}\text { Peningkatan efisiensi produksi } \\
\text { Production efficiency scenario }\end{array}$ & $6.697,736$ & $73.211,057$ \\
$\begin{array}{l}\text { Penanaman lahan kosong } \\
\text { Land investment scenario }\end{array}$ & $4.037,550$ & $81.207,522$ \\
$\begin{array}{l}\text { Fair trade dengan penghilangan biaya transaksi } \\
\text { Fair trade through the reduction of transaction cost }\end{array}$ & $4.258,435$ & $48.985,407$ \\
\hline
\end{tabular}

Distribusi nilai tambah pada rantai ...... (Nunung Parlinah, Herry Purnomo and Bramasto Nugroho) 
Untuk mengimplementasikan berbagai alternatif skenario di atas, beberapa hal yang harus diperhatikan adalah.

(1) Skenario pertama: Tingkat efisiensi penggergajian antara lain tergantung dari kualitas log, ukuran kayu gergajian yang diinginkan serta kualitas dari mesin gergajinya sendiri. Efisiensi dari proses pembuatan mebel dapat ditempuh melalui diversifikasi produk dalam satu unit manajemen baik dari segi desain maupun kualitas mebel yang disesuaikan dengan ketersediaan bahan baku yang ada. Tantangan yang dihadapi adalah perlunya mencari peluang pasar baru selain pasar yang sudah ada (fokus strategi diversifikasi (Barclay et al. 2000)), diimbangi dengan peningkatan kemampuan pengrajin di bidang pemasaran.

(2) Skenario kedua: Hasil simulasi pada skenario penanaman lahan kosong di Perhutani KPH Pati masih menunjukkan kecenderungan turunnya volume produksi kayu mahoni. Agar penerapan skenario ini dapat berhasil, maka perlu adanya dukungan dana yang lebih besar untuk penanaman, dan hal terpenting adalah penerapan kebijakan yang tepat untuk pengelolaan hutan Perhutani sehingga tekanan terhadap kelestarian hutan dapat dikurangi. Untuk usaha hutan rakyat, perlu kebijakan yang bersifat insentif serta dapat meningkatkan faktor endowment berupa peningkatan kapasitas menahan stock

(3) Skenario ketiga: Tantangan yang dihadapi dalam implementasinya adalah membangun kesepahaman melalui aksi kolektif (collective action) dan aturan main yang dapat menekan adanya biaya transaksi. Aksi kolektif ini antara lain dapat diterapkan dalam memanfaatkan pasar mebel yang memberikan harga premium. Aksi kolektif juga dapat diterapkan untuk memperkuat posisi jual pengrajin melalui penguatan peran asosiasi pengrajin yang sudah terbentuk.

\section{KESIMPULAN DAN SARAN}

Bisnis di bidang pengusahaan mebel mahoni baik pasar domestik maupun pasar ekspor melibatkan banyak pelaku mulai dari penanam kayu sampai kepada retailer. Dalam bisnis tersebut setiap pelaku memperoleh nilai tambah, dimana nilai tambah tersebut tidak terdistribusi secara merata. Pelaku yang paling banyak memperoleh nilai tambah per $\mathrm{m}^{3}$ bahan baku pada pasar domestik adalah pengecer (+fiishing) 49,83\%, pada pasar ekspor untuk bahan baku yang berasal dari kayu rakyat dan Perhutani adalah eksportir (+finishing) masing-masing sebesar 36,79\% dan 31\%. Pada kedua pasar tersebut, yang paling sedikit memperoleh nilai tambah adalah pemberi jasa penggergajian.

Simulasi dasar terhadap model menunjukkan bahwa nilai tambah total pada pasar domestik mengalami peningkatan, sementara nilai tambah total pada pasar ekspor mengalami penurunan. Beberapa skenario kebijakan yang dapat diterapkan adalah:

(1) Efisiensi pada proses pembuatan mebel melalui diversifikasi produk dan perlunya mencari peluang pasar baru disertai dengan peningkatan kemampuan pengrajin di bidang pemasaran.

(2) Peningkatan volume produksi kayu melalui penanaman lahan kosong di Perhutani disertai dengan penerapan kebijakan pengelolaan yang tepat untuk mengurangi tekanan terhadap hutan dapat dikurangi. Kebijakan yang bersifat insentif untuk usaha hutan rakyat antara lain kebijakan kredit tunda tebang.

(3) Penerapan fairtrade melalui aksi kolektif dan kerjasama diantara para pelaku. Aksi kolektif untuk memperkuat posisi jual pengrajin antara lain melalui pengendalian harga jual mebel 
oleh asosiasi pengrajin yang telah terbentuk, sehingga dapat memperoleh bagian keuntungan yang lebih baik. Peningkatkan posisi jual pengrajin juga dapat ditempuh melalui penguatan modal, sehingga kapasitas menahan stock meningkat. Peranan yang intensif dari pemerintah sangat diperlukan karena aksi kolektif sangat rentan terhadap perilaku oportunis.

\section{DAFTAR PUSTAKA}

Asmindo Komda Jepara. 2008. Menuju Tata Niaga Industri Furniture Berdaya Saing Global (5 Tahun Membangun Industri Furniture Jepara). Asmindo komda jepara 2002 - 2007. Jepara.

BAPPEDA dan BPS Kabupaten Jepara. 2007. Produk Domestik Regional Bruto Kabupaten Jepara 2006. Badan Pusat Statistik Kabupaten Jepara. Jepara.

Barclay I, Dann Z, Holroyd P. 2000. New Product Development: A Practical Workbook for Improving Performance. Butterworth - Heinemann: Oxford.

CITES. 2007. Appendices I, II and III valid from 3 May 2007. http://www.cites.org/ [21 Juni 2007]

Ewasechko AC. 2005. Upgrading the Central Java Wood Furniture Industry: A Value Chain Approach. International Labour Organization. Philippines.

Grant E, Ellen KP, Sandra SL. 1997. Ecology and Natural Resource Management, System Analysis and Simulation. Toronto: John Willey \& Son, Inc.

[ITTO] International Tropical Timber Organization. 2006. Tropical Timber Market Report 11 (15). ITTO. Yokohama.

Kaplinsky R dan Morris M. 2000. A Handbook for Value Chain Research. http://www.ids.ac.uk/ids/global/pdfs/VchNov01.pdf. [3 September 2007]

Kaplinsky R, Memedovic O, Morris M, Readman J. 2003. The Global Wood Furniture Value Chain: What Prospects for Upgrading by Developing Countries. United Nations Industrial Development Organization. Viena.

Kaplinsky R, Readman J. 2001. Integrating SMEs in Global Value Chains towards Partnership for Development. United Nations Industrial Development Organization. Viena.

Purnomo H. 2006. Teak furniture and business responsibility: A global value chain dynamics approach. Economics and Finance in Indonesia 54 (3): 411 - 443.

Purnomo H. 2005. Teori sistem kompleks, pemodelan dan manajemen sumberdaya adaptif. Fakultas Kehutanan, Institut Pertanian Bogor. Tidak Diterbitkan. Bogor

Roda JM, Cadène P, Guizol P, Santoso L, dan Fauzan AU. 2007. Atlas Industri Mebel Kayu di Jepara, Indonesia. CIRAD dan CIFOR. Bogor.

USAID-SENADA. 2007. Tinjauan Rantai Nilai Industri (RNI) Mebel: Mekanisme Operasi dan Antarhubungan Perusahaan dalam RNI Mebel. USAID - SENADA.

Distribusi nilai tambah pada rantai ...... (Nunung Parlinah, Herry Purnomo and Bramasto Nugroho) 